Chronic Obstructive Pulmonary Diseases: Journal of the COPD Foundation

\title{
Review
}

\section{Intravenous Alpha-1 Antitrypsin Therapy for Alpha-1 Antitrypsin Deficiency: The Current State of the Evidence}

Mark L. Brantly, MD ${ }^{1}$ Jorge E. Lascano, MD $^{1}$ Abbas Shahmohammadi, MD ${ }^{1}$

\begin{abstract}
Alpha-1 antitrypsin deficiency (AATD) is a largely monogenetic disorder associated with a high risk for the development of chronic obstructive pulmonary disease (COPD) and cirrhosis. Intravenous alpha-1 antitrypsin (AAT) therapy has been available for the treatment of individuals with AATD and COPD since the late 1980s. Initial Food and Drug Administration (FDA) approval was granted based on biochemical efficacy. Following its approval, the FDA, scientific community and third-party payers encouraged manufacturers of AAT therapy to determine its clinical efficacy. This task has proved challenging because AATD is a rare, orphan disorder comprised of individuals who are geographically dispersed and infrequently identified. In addition, robust clinical trial outcomes have been lacking until recently. This review provides an update on the evidence for the clinical efficacy of intravenous AAT therapy for patients with AATD-related emphysema.
\end{abstract}

Abbreviations: alpha-1 antitrypsin deficiency, AATD; chronic obstructive pulmonary disease, COPD; alpha-1 antitrypsin, AAT; Food and Drug Administration, FDA; neutrophil elastase, NE; alpha-1 proteinase inhibitor, $\mathbf{A}_{\mathbf{1}}$-PI; open label extension, OLE; forced expiratory volume in 1 second, FEV $\mathbf{1}$; computed tomography, CT; quality of life, QoL; randomized controlled trial, RCT; St George's Respiratory Questionnaire, SGRQ; total lung capacity, TLC; functional residual capacity, FRC; desmosine, DES; isodesmosine, IDES; graft versus host disease, GVHD Funding Support: Medical writing assistance was funded by CSL Behring.

Date of Acceptance: March 30, 2018

Citation: Brantly ML, Lascano JE, Shahmohammadi A. Intravenous alpha-1 antitrypsin therapy for alpha- 1 antitrypsin deficiency: the current state of the evidence. Chronic Obstr Pulm Dis. 2019;6(1):100-114. doi: https://doi.org/10.15326/jcopdf.6.1.2017.0185

1 Division of Pulmonary, Critical Care and Sleep Medicine, University of Florida, Gainesville

\section{Keywords:}

AAT therapy; alpha-1 antitrypsin deficiency; clinical efficacy; disease modification; COPD; emphysema

\section{Address correspondence to:}

Mark L. Brantly, MD

Division of Pulmonary, Critical Care, and Sleep Medicine

College of Medicine

University of Florida

JHMHC PO Box 100225

Gainesville, FL 32610

Email: mbrantly@ufl.edu

Phone: (352)273-8737

\section{Introduction}

Alpha-1 antitrypsin (AAT) is a polyfunctional protein of the SERPIN family. ${ }^{1}$ One of its best understood functions is the inhibition of neutrophil elastase (NE), whose principal function is the proteolytic degradation of matrix proteins. ${ }^{1,2}$ Genetic deficiency of AAT results in an imbalance in activity between the proteinase (NE) and the anti-proteinase (AAT). ${ }^{3}$ This imbalance can lead to the breakdown of elastin in tissues principally in the parenchyma of the lung. ${ }^{3}$ As a result, individuals with severe alpha- 1 antitrypsin deficiency (AATD), most commonly with the $\mathrm{PI}^{*} \mathrm{ZZ}$, or $\mathrm{PI}{ }^{*} \mathrm{SZ}$ genotypes or absence of the gene (PI*NullNull), are predisposed to early-onset emphysema. ${ }^{4}$ In addition, there is emerging evidence that AAT has several other 
functions that are thought to modulate inflammation in the lung and elsewhere. ${ }^{5}$

Despite the status of AATD as a rare disease, it is one of the most common fatal genetic disorders, and respiratory failure accounts for as much as $45 \%$ of deaths in never smoking AATD patients. ${ }^{6}$ AATD can also predispose to liver disease; as the protein is synthesized within hepatocytes, damage predominantly results from the aggregation of AAT caused by the $\mathrm{PI}^{*} \mathrm{ZZ}$ mutation and to a lesser extent by the $\mathrm{PI}{ }^{*} \mathrm{SZ}$ variant. ${ }^{7}$ Liver disease is an often neglected aspect of AATD and it is interesting to note that, in a screening study, cirrhosis was found to account for $10 \%$ of deaths in AATD patients. ${ }^{8}$

Worldwide, there are estimated to be 181,894 and 1,269,054 individuals with the $\mathrm{PI}^{*} \mathrm{ZZ}$ and $\mathrm{PI}{ }^{*} \mathrm{SZ}$ genotypes, respectively. ${ }^{9}$ However, only a small fraction of these individuals have been identified and most patients are identified long after symptoms begin. ${ }^{10}$ Importantly, non-affected and or mildly affected AATdeficient individuals never develop life-threatening lung disease if early identification is coupled with smoking cessation and lifestyle counseling. Individuals with AAT deficiency and symptoms may benefit from AAT therapy. ${ }^{2}$ However, the initial diagnosis can be challenging as AATD-related chronic obstructive pulmonary disease (COPD) has no unique features that separate it from non-genetic COPD. ${ }^{11}$ To identify AAT deficient individuals, genetic testing is an absolute requirement. Furthermore, testing methods should take into consideration both quantitative levels of AAT and the patient's genotype or AAT Pi-type to gain an accurate picture of the individual patient risk. ${ }^{12,13}$

The antitrypsin activity of AAT was first described in the 1950 s by Jacobsson. ${ }^{14,15}$ The protein was later isolated by Laurell and Eriksson in the early 1960s, with some suggestion from case reports that low serum levels in patients were contributing to lung disease. ${ }^{16}$ Later, AAT was found to inhibit NE with a greater affinity, leading to the introduction of the nomenclature alpha-1 proteinase inhibitor ( $\left.\mathrm{A}_{1}-\mathrm{PI}\right)$. Since the discovery of a genetic deficiency in AAT, efforts have focused on isolating and purifying the protein from human plasma, in order to supplement patients with a deficiency. ${ }^{3}$ This has resulted in the development of products (Figure 1) aimed at raising serum levels of AAT in patients with AATD above a theoretical "protective" threshold of $11 \mu \mathrm{M}$. This level is equivalent to the 10th percentile of the AAT range of $\mathrm{PI}^{*} \mathrm{SZ}$

\section{Figure 1. Historical Overview of the Development of Alpha-1 Antitrypsin Therapy}

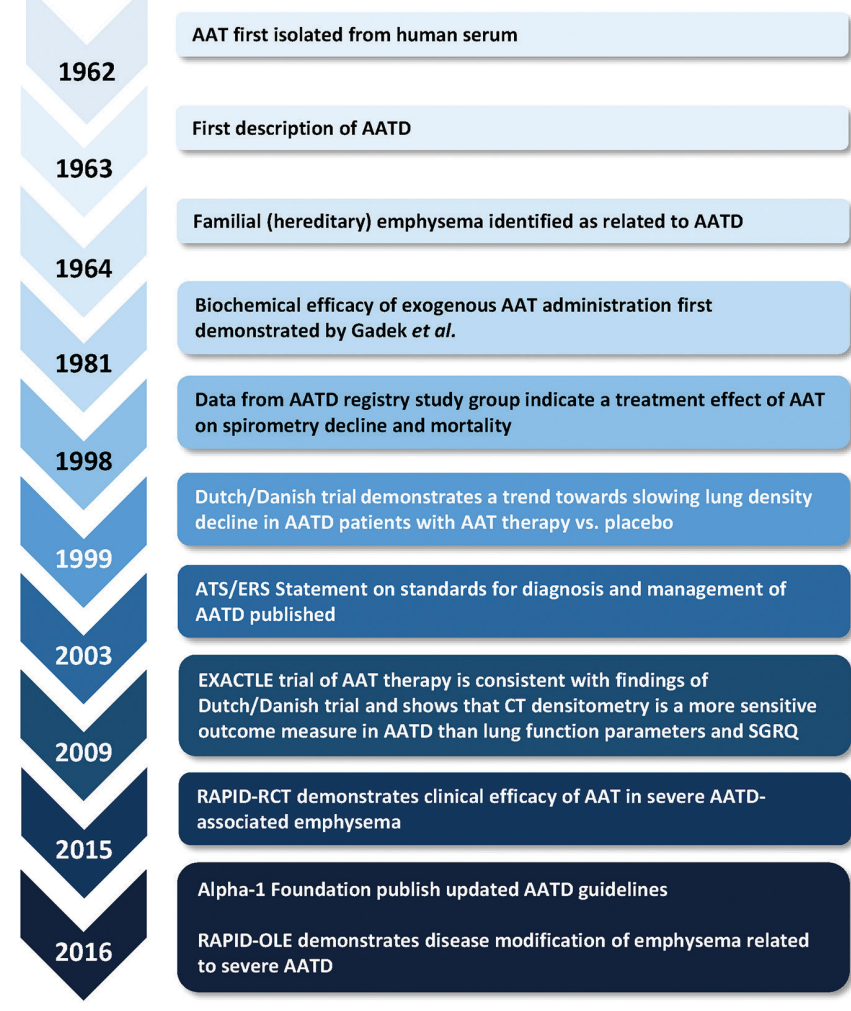

AAT=alpha- 1 antitrypsin; AATD=alpha- 1 antitrypsin deficiency; ATS $/$ ERS=American Thoracic Society /European Thoracic Society $\mathrm{CT}=$ computed tomography; $\mathrm{RCT}=$ randomized controlled trial; OLE=open-label extension

individuals, with epidemiological data suggesting a lower probability of COPD above this level. ${ }^{17,18}$ Proving the efficacy of exogenous administration of AAT in AATD beyond the biochemical elevation of anti-elastase capacity, i.e., the clinical efficacy to slow emphysema progression, has proved to be more difficult. This has been in part due to the orphan status of the disease and the previously discussed barriers to diagnosis, but has also been confounded by a lack of sensitive clinical study endpoints to monitor disease progression. ${ }^{19}$ As a result, the treatment of AATD with intravenous AAT therapy has remained a controversial topic and has hampered efforts to raise awareness of the disease.

This review aims to update a previous publication by Tonelli and Brantly (2010) ${ }^{2}$ in light of the publication of data from several recent clinical studies, notably, data from the RAPID clinical trial program - the largest clinical trials of AAT therapy on emphysema 
progression in AATD completed to date. The present review will focus on and reassess the clinical evidence for the efficacy of exogenous AAT therapy administration to treat patients with emphysema related to severe AATD. The evidence for other clinical uses of AAT therapy will also be covered.

\section{Search Strategy and Selection Criteria}

For the present narrative review, literature was sourced from the references listed in the Tonelli and Brantly ${ }^{2}$ paper. PubMed searches were performed to identify clinical trials as well as clinical and pre-clinical studies of AAT therapy published since 2010 that were not included in the original paper. Search terms included: "alpha-1 proteinase/alpha-1 antitrypsin AND emphysema”; "AATD AND clinical trial”.

\section{Current State of the Evidence for Alpha-1 Antitrypsin Therapy}

\section{Biochemical Efficacy}

The biochemical efficacy of AAT therapy has been well established in numerous studies - doses of $60 \mathrm{mg} / \mathrm{kg}$ and above raise serum levels above the theoretical protective threshold of $11 \mu \mathrm{M}$ and increase the inhibition of NE. ${ }^{3,20-28}$ To date, only the $60 \mathrm{mg} / \mathrm{kg} / \mathrm{wk}$ dose has been proven to maintain AAT serum levels consistently above $11 \mu \mathrm{M}$. Following longer dosing intervals and higher doses (i.e., $120 \mathrm{mg} / \mathrm{kg}$ biweekly and $250 \mathrm{mg} / \mathrm{kg}$ monthly), serum AAT levels were found to fall below the therapeutic threshold before the next scheduled dose. ${ }^{21,22}$

Recent studies evaluating the biochemical efficacy of AAT since the publication of the previous review ${ }^{2}$ are shown in Table 1. A recent pharmacokinetic study by Campos et al (2013) ${ }^{26}$ comparing $120 \mathrm{mg} / \mathrm{kg}$ versus $60 \mathrm{mg} / \mathrm{kg}$ AAT weekly demonstrated that the higher dose achieved a significantly higher trough level (27.7 versus $17.3 \mu \mathrm{M})$. However, clearance of the higher dose was faster: half-lives were 184.3 hours versus 212.7 hours for $120 \mathrm{mg} / \mathrm{kg}$ and $60 \mathrm{mg} / \mathrm{kg}$, respectively. ${ }^{26}$ The Campos et al study demonstrated no difference in adverse event rates between the 2 doses. This latter observation is supported by data from the RAPID clinical trial program; patients received a higher bi-weekly dose of $120 \mathrm{mg} / \mathrm{kg}$ to cover periods where they were unable to receive weekly infusions, e.g., for vacations. ${ }^{29}$ Both the 60 and
$120 \mathrm{mg} / \mathrm{kg}$ doses achieved serum levels above $11 \mu \mathrm{M}$ and were associated with similar adverse event rates to placebo, with no serious adverse events deemed to be treatment-related. ${ }^{29}$ Recently, a sub-analysis of the RAPID clinical trial program confirmed the stability of weight-based dosing of $60 \mathrm{mg} / \mathrm{kg} / \mathrm{wk}$ in achieving the $11 \mu \mathrm{M}$ threshold, as higher/lower weight than the average was predicted to have little effect on achieved serum levels. 30

Despite most biochemical studies focusing on achieving the putative $11 \mu \mathrm{M}$ protective threshold, there remains controversy surrounding the clinical meaning of this level - this topic is discussed further in the questions section. In addition, while higher doses of AAT therapy may be beneficial in some patients, the long-term safety of higher doses remains unanswered and ongoing studies will seek to address this issue. ${ }^{31}$

\section{Clinical Efficacy in Lung Disease}

In attempting to demonstrate the clinical efficacy of AAT therapy, various clinical endpoints have been assessed, including spirometry (forced expiratory volume in 1 second $\left[\mathrm{FEV}_{1}\right]$ ), exacerbations, lung density measured by computed tomography (CT), quality of life (QoL) and mortality. The evidence for the efficacy of AAT therapy on these endpoints is discussed below. Recent studies published since 2010 that have investigated the clinical efficacy of AAT therapy are shown in Table 2.

\section{Effect on Spirometry}

To show a statistically significant effect of AAT therapy on emphysema progression using $\mathrm{FEV}_{1}$ in a randomized, placebo-controlled trial, it was originally estimated that around 300 patients would need to be followed over 3 years. ${ }^{19}$ This represented a significant logistical challenge, owing to the previously discussed difficulties surrounding diagnosis coupled with the orphan status of the disease. Observational and registry studies were, therefore, the best approach to gain an indication of the natural history of AATD and efficacy of treatment. Several studies noted a significant effect of AAT therapy on $\mathrm{FEV}_{1}$ decline, most notably within specific $\mathrm{FEV}_{1}$ ranges. ${ }^{32-36}$ The largest pool of spirometry data published in 1999 by the Alpha-1 Antitrypsin Deficiency Registry Study Group suggested that AAT therapy was effective between the $\mathrm{FEV}_{1}$ range of $35 \%$ and $49 \%$ predicted. ${ }^{33}$

Despite evidence of a therapeutic effect on $\mathrm{FEV}_{1}$ in 


\section{Table 1. Studies Exploring Biochemical Efficacy of Alpha-1 Antitrypsin Therapy - Updates Since 2010}

\begin{tabular}{|c|c|c|c|c|c|c|}
\hline Study & Design & $\begin{array}{l}\text { Medication } \\
\text { and } \\
\text { Dose }\end{array}$ & $n$ & $\begin{array}{l}\text { Treatment } \\
\text { Duration }\end{array}$ & Results & $\begin{array}{l}\text { Number } \\
\text { of Days } \\
\text { Serum } \\
\text { Level } \\
\text { Above } \\
\text { Threshold }\end{array}$ \\
\hline $\begin{array}{l}\text { Campos } \\
\text { et al } \\
{[2013]^{26}}\end{array}$ & $\begin{array}{l}\text { Randomized, double- } \\
\text { blind crossover study } \\
\text { (SPARK) }\end{array}$ & $\begin{array}{l}\text { Prolastin-C } \\
60 \mathrm{mg} / \mathrm{kg} \\
\text { weekly vs } \\
\text { Prolastin- } \mathrm{C}^{\circledR 8} \\
120 \mathrm{mg} / \mathrm{kg} \\
\text { weekly }\end{array}$ & PC: 30 & $\begin{array}{l}\text { Cross over } \\
\text { study: } 8 \\
\text { weeks each } \\
\text { on } 60 \mathrm{mg} / \mathrm{kg} \\
\text { and } 120 \mathrm{mg} / \mathrm{kg}\end{array}$ & $\begin{array}{l}\text { Higher } \mathrm{C}_{\max }, \mathrm{AUC} \mathrm{C}_{0}-7 \text { days } \\
\text { and } \mathrm{C}_{\text {trough }} \text { with } 120 \mathrm{mg} / \\
\mathrm{kg} \text { dose but lower } \mathrm{t}_{1 / 2} \\
\text { Similar number of AEs } \\
\text { with both doses }\end{array}$ & $7 / 7$ \\
\hline $\begin{array}{l}\text { Sandhaus } \\
\text { et al } \\
{[2014]^{27}}\end{array}$ & $\begin{array}{l}\text { Non-inferiority, } \\
\text { randomized, double- } \\
\text { blind with partial } \\
\text { crossover }\end{array}$ & $\begin{array}{l}\text { A1PI-GLASSIA } \\
\text { vs Prolastin }^{8}\end{array}$ & $\begin{array}{l}\text { G: } 33 \\
\text { P: } 17\end{array}$ & $\begin{array}{l}\text { Double-blind: } \\
24 \text { weeks }\end{array}$ & $\begin{array}{l}\text { Bioequivalence of the } 2 \\
\text { preparations }\end{array}$ & $7 / 7$ \\
\hline $\begin{array}{l}\text { Seersholm } \\
\text { et al } \\
{[2015]^{29}}\end{array}$ & $\begin{array}{l}\text { Randomized placebo- } \\
\text { controlled trial - sub- } \\
\text { analysis of RAPID } \\
\text { study }\end{array}$ & $\begin{array}{l}\text { Zemaira }^{\circledR 2} \\
120 \mathrm{mg} / \mathrm{kg} \\
\text { bi-weekly vs } \\
\text { placebo } \\
\text { bi-weekly }\end{array}$ & $\begin{array}{l}Z: 75 \\
\text { (333 infusions) } \\
\text { PB: } 70 \\
\text { (374 infusions) }\end{array}$ & $\begin{array}{l}\text { Double-blind: } \\
4 \text { years }\end{array}$ & $\begin{array}{l}\text { Ctrough } 12.1 \mu \mathrm{M} \text { with } \\
120 \mathrm{mg} / \mathrm{kg} \\
\text { Similar number of AEs } \\
\text { compared with placebo }\end{array}$ & $\begin{array}{r}14 / 14 \\
\text { (based on } \\
\text { limited } \\
\text { compliant } \\
\text { samples } \\
[n=17])\end{array}$ \\
\hline $\begin{array}{l}\text { Tortorici } \\
\text { et al } \\
{[2017]^{30}}\end{array}$ & $\begin{array}{l}\text { Dose-exposure and } \\
\text { exposure-response } \\
\text { modeling of RAPID/ } \\
\text { RAPID Extension } \\
\text { trial data }\end{array}$ & $\begin{array}{l}\text { Zemaira }^{(8)} \\
60 \mathrm{mg} / \mathrm{kg} \\
\text { weekly vs } \\
\text { placebo }\end{array}$ & $\begin{array}{l}Z: 93 \\
\text { PB: } 87\end{array}$ & $\begin{array}{l}\text { Double-blind: } \\
4 \text { years }\end{array}$ & $\begin{array}{l}\text { Confirmation of weight- } \\
\text { based dosing as } \\
\text { appropriate treatment } \\
\text { strategy; } \\
\text { Prediction of linear } \\
\text { relationship between dose } \\
\text { and exposure; } \\
\text { Higher doses may result } \\
\text { in greater clinical effect }\end{array}$ & $7 / 7$ \\
\hline $\begin{array}{l}\text { Barker } \\
\text { et al } \\
{[2017]^{28}}\end{array}$ & $\begin{array}{l}\text { Non-inferiority, } \\
\text { randomized, double- } \\
\text { blind, crossover }\end{array}$ & $\begin{array}{l}\text { Liquid } \\
\text { Alpha1-PI } \\
\text { (Grifols) } \\
\text { vs } \\
\text { Prolastin-C }\end{array}$ & $\begin{array}{l}\text { LAPI: } 16 \\
\text { PC: } 16\end{array}$ & $\begin{array}{l}\text { Double-blind: } \\
16 \text { weeks }\end{array}$ & $\begin{array}{l}\text { Bioequivalence of } \\
\text { the } 2 \text { preparations }\end{array}$ & $7 / 7$ \\
\hline
\end{tabular}

$\mathrm{PC}=$ Prolastin $=\mathrm{C}^{8} ; \mathrm{C}_{\max }=$ maximum concentration; $\mathrm{AUC}_{0-7 \text { days }}=$ area under curve from $0-7$ days; $\mathrm{C}_{\text {trough }}=$ trough concentration; $\mathrm{t} 1 / 2=\mathrm{half}$ life; $\mathrm{AE}=$ adverse events; $\mathrm{A} 1 \mathrm{PI}=$ alpha-1 proteinase inhibitor; $\mathrm{G}=\mathrm{A} 1 \mathrm{PI}-\mathrm{Glassia} ; \mathrm{P}=\mathrm{Prolastin}{ }^{\mathbb{8}} ; \mathrm{Z}=\mathrm{Zemaira}{ }^{\mathbb{8}}$; $\mathrm{PB}=$ placebo; LAPI=alpha-1 proteinase inhibitor

observational or registry studies, clinical studies have failed to demonstrate a significant effect, in part due to smaller sample sizes and length of follow-up. ${ }^{37,38}$ A meta-analysis by Chapman et al (2009) pooled data from 5 studies ( $N=1509)$ and concluded that the rate of $\mathrm{FEV}_{1}$ decline was $23 \%$ less in patients receiving
AAT therapy, with the difference predominantly seen in patients with $\mathrm{FEV}_{1} 30 \%-65 \%$ predicted. $^{39}$ No significant effect was shown with values above or below this range. However, as $\mathrm{FEV}_{1}$ has low sensitivity in AATD, ${ }^{38}$ these data do not rule out the possibility that AAT is effective in more or less advanced disease. 


\section{Table 2. Studies Exploring Clinical Efficacy of Alpha-1 Antitrypsin Therapy - Updates Since 2010}

\begin{tabular}{|c|c|c|c|c|c|c|c|}
\hline Study & Design & $\begin{array}{l}\text { FEV } 1 \% \\
\text { Predicted } \\
\text { at Inclusion } \\
\text { Treated/ } \\
\text { Non-treated }\end{array}$ & $\begin{array}{c}\text { n; } \\
\text { Treated/ } \\
\text { Non- } \\
\text { treated }\end{array}$ & $\begin{array}{c}\text { Results in Treated } \\
\text { Versus Non- } \\
\text { treated Patients }\end{array}$ & $\begin{array}{l}\text { Sub- } \\
\text { group } \\
\text { That } \\
\text { Bene- } \\
\text { fited the } \\
\text { Most }^{a}\end{array}$ & $\begin{array}{l}\text { Follow- } \\
\text { up } \\
\text { Time }\end{array}$ & $\begin{array}{c}\text { Medication } \\
\text { and } \\
\text { Dosing }\end{array}$ \\
\hline $\begin{array}{l}\text { Stockley } \\
\text { et al } \\
{[2010]^{43}}\end{array}$ & $\begin{array}{l}\text { Combined } \\
\text { analysis of } \\
\text { Dirksen et al } \\
\text { trials }\end{array}$ & $\begin{array}{r}48.0 \pm 16.4 \% \\
\text { vs } \\
47.9 \pm 18.6 \%\end{array}$ & $60 / 59$ & $\begin{array}{l}\text { Change in lung density: } \\
-4.082 \mathrm{~g} / \mathrm{L} \text { for treated and } \\
-6.379 \mathrm{~g} / \mathrm{L} \text { for placebo: } \\
\text { treatment difference of } 2.297 \\
(95 \% \mathrm{CI}, 0.669 \text { to } 3.926 ; \\
p=0.006)\end{array}$ & $\mathrm{N} / \mathrm{A}$ & 2.5 years & $\begin{array}{l}\text { AAT (Lille, } \\
\text { France) } \\
250 \mathrm{mg} / \mathrm{kg} \text { every } \\
4 \text { weeks / } \\
\text { Prolastin }^{\circledR} \\
60 \mathrm{mg} / \mathrm{kg} \text { weekly }\end{array}$ \\
\hline $\begin{array}{l}\text { Barros- } \\
\text { Tizón } \\
\text { et al } \\
{[2012]^{56}}\end{array}$ & $\begin{array}{l}\text { Observational, } \\
\text { retrospective }\end{array}$ & $\mathrm{N} / \mathrm{A}$ & 127 & $\begin{array}{l}\text { Reduced severe } \\
\text { exacerbations }\end{array}$ & $\mathrm{N} / \mathrm{A}$ & $\begin{array}{l}18 \text { months } \\
\text { AAT therapy }\end{array}$ & $\begin{array}{l}\text { Trypsone }^{(\mathbb{R}} \text { or } \\
\text { Prolastin }^{(\mathbb{R}}\end{array}$ \\
\hline $\begin{array}{l}\text { Rahaghi } \\
\text { et al } \\
{[2014]^{49}}\end{array}$ & $\begin{array}{l}\text { Re-analysis of } \\
\text { the Alpha-1 } \\
\text { Antitrypsin } \\
\text { Deficiency } \\
\text { Registry } \\
\text { Group data }\end{array}$ & $\begin{array}{r}37 \pm 18 \% \\
\text { vs } \\
74 \pm 35 \%\end{array}$ & $747 / 382$ & Improves survival & $\begin{array}{r}<20 \%, \\
<30 \% \\
\text { and } \\
\leq 65 \%\end{array}$ & $\begin{array}{l}\text { Median } \\
4.3 \text { years }\end{array}$ & N/A \\
\hline $\begin{array}{l}\text { Chapman } \\
\text { et al } \\
\text { [2015] } \\
\text { (RAPID- } \\
\text { RCT) }\end{array}$ & $\begin{array}{l}\text { Randomized, } \\
\text { double-blind } \\
\text { Placebo- } \\
\text { controlled }\end{array}$ & \begin{tabular}{|}
$47.4 \pm 12.1 \%$ \\
vs \\
$47.2 \pm 11.1 \%$ \\
\end{tabular} & $93 / 87$ & $\begin{array}{l}\text { Statistically significant } \\
\text { decrease in rate of } \\
\text { emphysema progression } \\
\text { by CT densitometry at TLC: } \\
0 \cdot 74 \mathrm{~g} / \mathrm{L} \text { per year }(95 \% \\
\text { CI } 0 \cdot 06-1 \cdot 42 ; p=0.03)\end{array}$ & $\mathrm{N} / \mathrm{A}$ & 2 years & $\begin{array}{l}\text { Zemaira }^{\circledR} \\
60 \mathrm{mg} / \mathrm{kg} \text { weekly }\end{array}$ \\
\hline $\begin{array}{l}\text { McElvaney } \\
\text { et al [2017] } \\
\text { (RAPID- } \\
\text { OLE) }\end{array}$ & $\begin{array}{l}\text { Open-label } \\
\text { extension to } \\
\text { Chapman } \\
\text { et al [2015] }\end{array}$ & $\mathrm{N} / \mathrm{A}$ & $\begin{array}{r}76 \\
\text { (Early- } \\
\text { Start) } \\
64 \\
\text { (Delayed- } \\
\text { Start) }\end{array}$ & $\begin{array}{l}\text { Efficacy sustained in Early- } \\
\text { Start group until Month } 48 \\
\text { and statistically significant } \\
\text { reduction in decline rate } \\
\text { between non-treatment and } \\
\text { treatment periods in } \\
\text { Delayed-Start group }(-1 \cdot 26 \mathrm{~g} / \\
\text { L/year [SE: } 0 \cdot 29], p=0.001)\end{array}$ & $\mathrm{N} / \mathrm{A}$ & 2 years & $\begin{array}{l}\text { Zemaira }^{(\mathbb{R}} \\
60 \mathrm{mg} / \mathrm{kg} \text { weekly }\end{array}$ \\
\hline
\end{tabular}

${ }^{a}$ Reduction in $\mathrm{FEV}_{1}$ decline in treated group

$\mathrm{FEV}_{1}=$ forced expiratory volume in 1 second; $\mathrm{CI}=$ confidence interval; N/A=not available; $\mathrm{AAT}=$ alpha -1 antitrypsin; $\mathrm{RCT}=\mathrm{randomized}$ controlled trial; $\mathrm{CT}=$ computed tomography; $\mathrm{TLC}=$ total lung capacity; $\mathrm{OLE}=$ open label extension; $\mathrm{SE}=$ standard error

Wencker et al (2001) found that the rate of lung function decline may be more important than initial disease severity when attempting to demonstrate treatment efficacy of AAT therapy. ${ }^{34}$ Contrary to findings from other studies, as described above, statistical significance for AAT treatment versus nontreatment was only reached in patients with baseline $\mathrm{FEV}_{1}>65 \%$. However, this was due to the majority of these patients exhibiting very fast $\mathrm{FEV}_{1}$ decline and consequently showing extremely large responses to treatment. This study also highlighted that individual decline in $\mathrm{FEV}_{1}$ can be non-linear. Furthermore, a recent analysis provides further evidence of the insensitivity of $F E V_{1}$ to detect changes in emphysema progression and AAT treatment effect in AATD ${ }^{40}$; this will be discussed in more detail later in the review. 
Overall, although an effect of AAT therapy on spirometric decline has been demonstrated in observational studies, use of this endpoint in clinical trials has been limited due to the need for larger numbers of patients and longer follow-up as indicated by power calculations. ${ }^{19,37}$ Therefore, endpoints with a higher sensitivity are required to assess the effect of AAT therapy on emphysema progression in AATD.

\section{Effect on Lung Density}

Although a treatment effect of AAT therapy was suggested by observational cohort studies, there are several limitations to these data, primarily the potential for investigator bias. High-quality evidence from a randomized controlled trial (RCT) was needed to confirm a treatment effect, and a key consideration for clinical studies was the use of highly sensitive and reliable endpoints. ${ }^{41} \mathrm{CT}$ lung densitometry has been shown to correlate with both pathological changes in the lungs and mortality, and was therefore approved by the FDA for use as a surrogate endpoint for emphysema progression in AATD. ${ }^{42}$

The Dirksen et al (1999) study of 26 Danish and 30 Dutch smokers was the first clinical trial to investigate the utility of CT-measured lung density in AATD. ${ }^{37}$ Although the trial was not powered to detect a statistically significant effect of treatment, a trend in favor of AAT therapy was shown, with an annual loss of lung tissue, as measured by CT, of $2.6 \pm 0.41$ $\mathrm{g} / \mathrm{L} / \mathrm{yr}$ for placebo compared with $1.5 \pm 0.41 \mathrm{~g} / \mathrm{L} / \mathrm{yr}$ for AAT ( $p=0.07)$. Power calculations indicated that a cohort of approximately 130 patients would have been sufficient to show a statistically significant effect. The subsequent EXACTLE study sought to further explore and refine the use of $\mathrm{CT}$ and compared the sensitivity of CT with other clinical outcome measures. ${ }^{38}$ Overall, CT was shown to have a higher sensitivity index score than lung function parameters, exacerbation frequency and QoL, as determined by the St George's Respiratory Questionnaire (SGRQ). The results from EXACTLE mirrored that of the Danish/Dutch trial: all methods of CT analysis favored AAT therapy versus placebo with $p$-values ranging between 0.049 and $0.084 .{ }^{38}$ In 2010 , a pooled analysis of the 2 RCTs found a statistically significant effect on lung density decline; overall decline rates were -1.73 and $-2.74 \mathrm{~g} / \mathrm{L} / \mathrm{yr}$, for AAT therapy and placebo, respectively $(p=0.006)^{43}$

Recently, data from the RAPID clinical trial program, the first adequately powered clinical trial in AATD, were published. ${ }^{44,45}$ RAPID-RCT was a multi-center, double-blind, placebo controlled trial of AAT therapy that recruited 180 AATD patients from 28 centers worldwide. After 2 years, non-U.S. patients were eligible to participate in an open-label extension phase (RAPID-OLE). During the 2-year extension study, patients who were previously assigned placebo in RAPID-RCT were switched to active treatment. In total, 140 patients (intention-to-treat population: 76 Early-Start and 64 Delayed-Start) continued treatment with AAT therapy, with 121 completing the full 4 years.

Over 2 years of the RAPID-RCT study, the annual rate of lung density decline was $-2.19 \mathrm{~g} / \mathrm{L}$ for placebo versus $-1.45 \mathrm{~g} / \mathrm{L}$ at total lung capacity (TLC; $p=0.03$ ). ${ }^{44}$ While a significant reduction in lung density decline rate was observed at TLC, results at functional residual capacity (FRC) alone or at TLC + FRC did not reach statistical significance. However, this difference can be explained by higher measurement error in CT scans at lower lung volumes. ${ }^{46}$ In the RAPID-OLE analysis; between Day 1 and Month 24, the annual decline rate at TLC was 33\% higher in Delayed-Start patients (Placebo - AAT) compared to Early-Start patients (AAT - AAT): -2.26 g/L/year versus - $1.51 \mathrm{~g} / \mathrm{L} /$ year; $p=0.021$. Treatment efficacy of AAT therapy was also maintained over 4 years in the Early-Start group. When patients in the Delayed-Start group were switched from placebo in RAPID-RCT to active treatment in RAPID-OLE, a statistically significant decrease or inflection point in the rate of lung density decline was observed. ${ }^{45}$ However, these patients failed to catch-up with the Early-Start group, due to the permanent loss of lung tissue, ${ }^{45}$ consistent with a "disease-modifying" effect of AAT therapy in AATD, i.e., a change in the natural history of disease progression. ${ }^{41}$

Recent CT efficacy data also challenge findings from observational studies showing an effect of AAT therapy on spirometric (FEV 1 ) decline at specific levels of baseline disease severity. A regression analysis comparing AAT therapy and placebo in all patients in RAPID-RCT found the treatment advantage with AAT (reduction in lung density decline rate) to be flat across all levels of baseline $\mathrm{FEV}_{1}$ impairment (between $27 \%$ and $79 \%$ predicted). ${ }^{40}$ These data suggest that efficacy of AAT therapy is independent of baseline FEV 1 and disease severity, although further data are needed to support these findings. 


\section{Mortality}

Emphysema related to AATD is a slowly progressing disease that is often fatal. To date, a mortality benefit of AAT therapy has not been confirmed in a clinical trial. Previous clinical trials have not been sufficiently powered to directly assess the effect of AAT therapy on mortality, with much larger sample sizes and longer duration placebo-controlled trials needed, particularly as a recent study by the U.K. ADAPT registry suggests that the majority of deaths occur after 4 to 9 years of follow-up. ${ }^{47}$ Nevertheless, observational studies have correlated lower lung density with reduced survival, providing an indirect indication of a mortality benefit with AAT therapy. ${ }^{47,48}$ The AATD registry suggested a beneficial effect on survival: mortality rate was statistically lower in the patients receiving AAT therapy compared with non-treated individuals, an effect predominantly observed in patients with an $\mathrm{FEV}_{1}<50 \%$ predicted. $^{33} \mathrm{~A}$ recent re-analysis of these data have shown a survival improvement also in patients with low baseline $\mathrm{FEV}_{1},<20 \%$ and $<30 \%$ predicted. ${ }^{49}$ However, a significant confounding factor for the AATD registry study was that the socioeconomic status of the treatment versus non-treatment cohorts could not be accounted for. In addition, a post-hoc extrapolation analysis of data from the RAPID clinical trial program suggests that AAT therapy can delay progression to terminal lung function $(\sim 20 \mathrm{~g} / \mathrm{L}$; defined as lung transplant, severe respiratory crisis or death) by 5.6 years. ${ }^{45}$

\section{Effect on Biomarkers}

There is increasing interest in the use of biomarkers to predict disease outcomes in COPD. A recent example is fibrinogen, increased levels of which have been shown to predict exacerbation risk and mortality. ${ }^{50}$

The main pathological process in AATD, the degradation of elastin, yields desmosine and isodesmosine (DES/IDES), biomarkers that have been investigated for their potential use in tracking disease progression and treatment efficacy in AATD. ${ }^{51}$ Previous studies have shown significantly lower levels of DES/IDES in patients receiving AAT therapy compared to patients not receiving treatment. ${ }^{52}$ Levels were also shown to be significantly higher in AATD patients compared to non-AATD controls, with those receiving AAT therapy statistically closer to normal individuals. The validity of DES/IDES as a biomarker in AATD is supported by a recent publication by $\mathrm{Ma}$ et al (2016) concerning the measured level of DES/IDES in patients during the RAPID clinical trial program. ${ }^{53}$ During RAPID-RCT, the levels of DES/IDES were statistically lower at all time points in the treated group compared with placebo. This effect was maintained in patients who originally received active treatment in RAPID-RCT (the Early-Start group) over the full 4 years of RAPID-RCT and RAPID-OLE. In the DelayedStart group, switching to active treatment at month 24 was associated with a significant reduction in DES/ IDES at months 36 and 48. A weak but significant correlation between changes in DES/IDES and the CT densitometry data at TLC was also shown $(\mathrm{R}=-0.256$, $P=0.005)$. DES/IDES show promise in providing a low-cost estimate of the severity of disease in AATD patients. However, such are the extremely small quantities of DES/IDES involved (in the nanogram per milliliter range) that highly sensitive analytical equipment is required. Further development of an assay for use in clinical trials is therefore necessary.

\section{Other Endpoints}

Other clinical endpoints have been investigated in clinical studies of AAT therapy, these include exacerbation frequency/severity and QoL, as assessed by the SGRQ.

Lung exacerbations are a significant health care burden in AATD and contribute substantially to poor outcomes and QoL. ${ }^{54}$ Two observational studies have reported beneficial effects of AAT therapy in reducing exacerbation frequency ${ }^{55,56}$; Barros-Tizon et al (2012) demonstrated a reduction in all $(p<0.05)$ and severe $(p<0.01)$ exacerbations in a cohort of 127 patients. This was reported to equate to a significant reduction in health expenditure per patient and was more apparent in patients who had previously experienced an exacerbation. ${ }^{56}$ However, although the cohort of patients were reportedly well-matched socioeconomically, the absence of a control group and the retrospective manner of the investigation are significant limitations. To date, a beneficial effect of AAT therapy on exacerbations has not been confirmed in several clinical trials. ${ }^{37,38,44}$ However, as AAT has significant anti-inflammatory properties, ${ }^{57}$ treatment may have a greater impact on exacerbation severity, rather than frequency. The EXACTLE clinical trial studied the effect of AAT therapy on exacerbations and reported an improvement in the qualitative severity of exacerbations following AAT treatment ${ }^{38}$; however, no 
specific details of this effect are provided. The effect of AAT therapy on exacerbations in AATD has yet to be confirmed and future clinical trials will have to be appropriately designed to fully investigate this.

The SGRQ is a commonly used QoL assessment tool in respiratory medicine. The SGRQ was included as a secondary endpoint in several clinical trials of AAT therapy completed to date. However, as no trials to date have been sufficiently powered to fully assess the effect of therapy on the SGRQ, owing to its low sensitivity index in AATD, ${ }^{38}$ they have failed to demonstrate a significant effect of therapy versus placebo. ${ }^{38,44,45}$

\section{Other Uses for Alpha-1 Antitrypsin}

Transplant

AAT therapy has been investigated for its potential in treating graft versus host disease (GVHD) in organ transplantation. Current evidence based on mouse models has shown that AAT treatment significantly reduces pro-inflammatory cytokines in GVHD post bone-marrow transplantation and can induce immune tolerance following pancreatic islet allograph transplantation. ${ }^{58,59}$ Due to the well-established safety profile of AAT therapy in humans, the treatment is currently being tested in Phase 1/2 open-label studies of AAT therapy in steroid refractory acute GVHD. ${ }^{60,61}$

\section{Diabetes}

Due to its anti-inflammatory activity and ability to protect pancreatic islets from immune destruction, AAT therapy has been investigated for its role in slowing the progression of recent-onset type-1 diabetes mellitus in children. ${ }^{62}$ Recent results from a Phase $1 / 2$ clinical trial were promising with at least 8 out of 24 patients showing a discernable response in terms of glycemic control. ${ }^{62}$

\section{Questions}

Answers to the following questions are based on evidence collated within this review, with updates on the 2010 Tonelli and Brantly paper.

\section{Why have clinical trials focused on CT Iung density rather than mortality?}

Despite limitations associated with the AATD registry study, its data are suggestive of a mortality effect questions may therefore be asked regarding why this has not been the focus of clinical trials. As discussed earlier in the review, to demonstrate a discernable effect on mortality in a clinical trial, a large number of patients would potentially need to be followed for up to 10 years. ${ }^{47}$ There are several factors that limit the feasibility of this, including difficulties in recruiting sufficient numbers of AAT-naive patients, ethical implications associated with administering placebo for this length of time and the overall expense of such a study. Due to these limitations, clinical trials have utilized CT lung density - a more sensitive outcome measures that correlates with mortality. ${ }^{47,48}$ By utilizing CT densitometry, clinical trials have demonstrated the treatment efficacy of AAT therapy in $\operatorname{AATD}^{37,38,44,45}$

In addition, extrapolation analyses, such as the post-hoc analysis of the RAPID clinical trial program, suggest that AAT treatment may extend the time to a terminal respiratory event (e.g., lung transplantation or death). However, this evidence of a mortality benefit is indirect, and direct mortality data has been highlighted by some as key to supporting clinical efficacy. ${ }^{63}$ Therefore, further mortality data is needed and longterm terminal lung density data could support the proposed life-extending effect of AAT therapy.

\section{Is there now sufficient evidence of clinical efficacy to recommend AAT therapy?}

Half a century after AAT was first isolated, there is now evidence that administration of AAT therapy raises serum levels and increases anti-elastase capacity, and that this biochemical effect translates into a measurable decrease in lung-function decline. Furthermore, it has now been shown that AAT therapy modifies the course of disease by slowing the rate by which lung tissue is degraded. Based on what is now known about the natural history of AATD and how AAT therapy can potentially alter the course of the disease, there is a sound basis for symptomatic patients with a genetically confirmed deficiency to be prescribed AAT therapy as outlined in the Alpha-1 Foundation Guidelines ${ }^{64}$ (Table 3). However, it should be noted that, with a recent sub-analysis of RAPID$\mathrm{RCT}$, there is emerging evidence to suggest that AAT therapy is effective at all levels of $\mathrm{FEV}_{1}$ impairment, and that treatment is therefore beneficial in both early- and late-stage disease. ${ }^{40}$ However, further data are needed to support this. Nevertheless, as evidence from the RAPID trial program demonstrates that lung tissue lost during periods of inactive treatment cannot 


\section{Table 3. Who Should Receive Alpha-1 Antitrypsin Therapy? Recommendations From the Alpha-1 Foundation ${ }^{64}$}

\section{AAT Therapy Is Recommended For:}

$\mathrm{FEV}_{1} \leq 65 \%$ predicted and genetically confirmed AATD

Over this threshold, treatment should be considered on an individual basis (e.g., fast decliners)

Necrotizing panniculitis

AAT Therapy Is NOT Recommended For:

$\mathrm{PI}^{*} \mathrm{MZ}$ individuals

Current smokers with AATD

AATD patients with bronchiectasis or emphysema but

with no airflow obstruction

Treatment of liver disease associated with AATD

Treatment in patients who have had a liver transplant

$\mathrm{AAT}=$ alpha- 1 antitrypsin; $\mathrm{FEV}_{1}=$ forced expiratory volume in 1 second; AATD=alpha-1 antitrypsin deficiency

be regained, earlier intervention may be beneficial for many AATD patients. Although the exact timing of treatment initiation is a decision for the treating physician, based on the patient's symptoms and the rate of deterioration in health status, the potential for earlier intervention is reflected in the Alpha-1 Foundation Guidelines. While a firm recommendation is provided for initiating AAT therapy in patients with $\mathrm{FEV}_{1} \leq 65 \%$ predicted, it is also recommended that the possibility of commencing therapy be discussed at all levels of spirometric decline above this threshold. ${ }^{64}$

\section{Should we expect a significant effect on quality-of-life outcomes?}

The SGRQ was designed to assess the effect of interventions that improve symptoms in COPD; however, while there is evidence that AAT therapy can slow disease progression, it cannot regain the lung tissue already lost pre-treatment, as demonstrated by the RAPID clinical trial program data. ${ }^{44,45}$ Moreover, the question of whether AAT therapy has an effect on exacerbations, a significant contributor to poor QoL outcomes, has yet to be conclusively determined. As the treatments and outcomes differ between COPD overall and AATD-related emphysema, there is an argument to be made that a QoL measure specific to AATD is needed to fully assess this question.

\section{Is $11 \mu M$ the right "protective threshold" below which patients should receive AAT therapy?}

As discussed previously, ${ }^{2}$ this target includes the endogenous, functionally deficient protein (in for example $\mathrm{PI}{ }^{*} \mathrm{ZZ}$ patients) and is a measure of the total antigenic, rather than the active level. Nevertheless, by utilizing the $11 \mu \mathrm{M}$ threshold as a point of reference, both observational studies and clinical trials (as summarized within this review) have demonstrated that elevating antigenic AAT levels above this level with the $60 \mathrm{mg} / \mathrm{kg} / \mathrm{wk}$ dose exerts a significant clinical effect. However, to date clinical studies have focused on confirming the efficacy of the standard $60 \mathrm{mg} / \mathrm{kg} / \mathrm{wk}$ and dose-optimization has yet to be explored. The recent pharmacometric analysis of the RAPID trials by Tortorici et al provides the first tentative indication that higher doses may yield a greater clinical effect. In the RAPID trials, due to higher body weight and different volumes of distribution, some patients had higher exposure levels of AAT and these patients tended to have greater reductions in the rate of lung density decline. ${ }^{44}$ When the data were modeled, a linear association between exposure and response (reduction in decline rate) was predicted - suggesting that higher doses may be associated with a greater clinical response. ${ }^{30}$ The authors, Tortorici et al, acknowledge that it is unlikely for the relationship between exposure and response to be completely linear and that a plateau would be expected. However, the plasma level at which this plateau occurs is likely to be beyond the traditional $11 \mu \mathrm{M}$ threshold, ${ }^{30}$ which is the target for the $60 \mathrm{mg} / \mathrm{kg} / \mathrm{wk}$ dose. The potential for greater efficacy on the rate of lung density decline with higher doses prompted the European Medicines Agency to request a post-marketing study following on from the RAPID trials to evaluate the efficacy of both $60 \mathrm{mg} / \mathrm{kg} / \mathrm{wk}$ and $120 \mathrm{mg} / \mathrm{kg} /$ wk doses. ${ }^{65}$ In addition, another clinical trial of AAT therapy efficacy on lung density with the same high/low dose design was also planned and is now active. ${ }^{31}$ Moreover, a recently completed small-scale clinical trial provides evidence of increased biological activity with higher doses. The study found that normalizing AAT serum levels in severe AATD patients with doses of $120 \mathrm{mg} / \mathrm{kg} /$ wk resulted in a significant reduction in inflammatory markers versus the $60 \mathrm{mg} / \mathrm{kg} / \mathrm{wk}$ dose. ${ }^{66}$ However, further research is required to establish whether increased anti-inflammatory activity translates into improved clinical outcomes. Therefore, as clinical 
evidence for increased efficacy with higher doses is scarce, doses $>60 \mathrm{mg} / \mathrm{kg} / \mathrm{wk}$ are not currently licensed and this is unlikely to change until clinical efficacy and long-term safety are demonstrated in a large-scale clinical trial.

\section{What is the correct dosing interval?}

As summarized within this review, several studies have experimented with extended and individualized dosing intervals. However, only the $60 \mathrm{mg} / \mathrm{kg}$ weekly dose has been shown to consistently maintain AAT serum levels above the $11 \mu \mathrm{M}$ threshold, and serum AAT levels have been shown to decrease below $11 \mu \mathrm{M} 1-2$ days prior to the next dose with $120 \mathrm{mg} / \mathrm{kg}$ biweekly. ${ }^{21}$ Despite the previously discussed limitations with the $11 \mu \mathrm{M}$ threshold, the clinical implications of not consistently raising levels above this threshold are uncertain, as most clinical efficacy data to date are based on the standard $60 \mathrm{mg} / \mathrm{kg} / \mathrm{wk}$ dose. However, recent data from the RAPID clinical trial program demonstrate that longer dosing intervals may be beneficial in certain situations, e.g., to cover vacations, and importantly, that higher doses are not associated with increased adverse events. ${ }^{29}$ Nevertheless, due to a lack of clinical efficacy data based on alternative dosing strategies, the standard $60 \mathrm{mg} / \mathrm{kg} / \mathrm{wk}$ dose should be the mainstay of treatment at the present time.

\section{How should patients on AAT therapy be followed?}

There is a lack of a clear consensus on this issue. As discussed previously, ${ }^{2}$ one firm recommendation from the original American Thoracic Society/European Respiratory Society statement is to measure FEV 1 on a yearly basis. ${ }^{12}$ There has previously been limited evidence for tracking AATD disease progression with CT densitometry; however, the RAPID clinical trial program data provide a sound basis to recommend the use of CT densitometry. The recently published Alpha-1 Foundation AATD guidelines provide a firm recommendation that all newly diagnosed, symptomatic AATD patients should have a baseline chest CT scan. ${ }^{64}$ However, serial chest CT scanning is not recommended owing to radiation dose and uncertainty regarding how exactly the results should be interpreted clinically. This recommendation may change in years to come as lower-radiation scanning is introduced and the value of quantifying the level of disease progression is fully understood.

\section{Should individuals with PI*MZ and PI*SZ receive AAT therapy?}

There is limited rationale for treating patients with intermediate deficiency (i.e., PI*MZ individuals), ${ }^{67}$ and there is currently no evidence to support this use of AAT therapy - this is reflected by a firm stance in the latest guidelines (Table 3). ${ }^{64}$ However, if a patient is found to have the $\mathrm{PI}^{*} \mathrm{MZ}$ genotype, the chance of a direct family member showing homozygosity is significantly higher (owing to Mendelian inheritance). ${ }^{12,64}$ Therefore, familial testing of $\mathrm{PI}^{*} \mathrm{MZ}$ individuals is advised. The $\mathrm{PI}^{*} \mathrm{SZ}$ genotype is considered to be a severe deficiency variant ${ }^{64}$; however, clinical presentation is highly variable and $\mathrm{PI}^{*} \mathrm{SZ}$ individuals make up a small percentage (as little as 4\%) of the lung pathologies associated with AATD. ${ }^{68}$ The decision of whether to treat $\mathrm{PI}^{*} \mathrm{SZ}$ patients therefore remains at the discretion of the treating physician based on AAT serum levels and clinical presentation. Furthermore, in recent years indications for treatment have moved away from narrow ranges of genotypes due to the high heterogeneity of the SERPINA1 gene, demonstrated by the large numbers of novel pathogenic mutations that continue to be discovered. Physicians are therefore encouraged to take a holistic approach and look at all aspects of AATD, from AAT serum levels to lung-function parameters and smoking status.

\section{Areas for Future Research}

1. Identifying an average terminal lung density threshold in AATD and emphysema to help quantify treatment-advantage with AAT therapy.

2. Dose optimization: now that the clinical efficacy of AAT therapy in AATD has been demonstrated, efforts should focus on identifying the optimal dosage/dosage interval.

3. Further study is required to confirm efficacy of AAT therapy in both early- and late-stage disease suggested by the RAPID-RCT data.

\section{Conclusions}

It is pleasing to see significant steps forward in the understanding of AATD. In the 8 years since the publication of the previous review, the RAPID clinical trial program has demonstrated that AAT therapy can significantly reduce lung density decline 
and is disease modifying. Nevertheless, despite the significant progress there remains doubt among some parties regarding the meaning of $\mathrm{CT}$ data and there is work required to conclusively link the reduction in rate of lung density decline to a mortality benefit. While it is difficult to demonstrate a mortality benefit of AAT therapy in a clinical study, data from the RAPID trial program indicate that treatment with AAT may delay the time to terminal lung function. Furthermore, the use of AAT therapy continues to be researched in other therapy areas, particularly in transplant and type-1 diabetes, in part due to its highly positive safety profile. Results from ongoing clinical trials in these areas are eagerly awaited.

\section{Declaration of Interest}

The authors have no conflicts of interest to declare. Medical writing assistance was provided by Steven Foster of Meridian HealthComms Ltd (Plumley, United Kingdom), funded by CSL Behring. 


\section{References}

1. Stoller JK, Aboussouan LS. A review of a1-antitrypsin deficiency. Am J Respir Crit Care Med. 2012;185(3):246-259. doi: https://doi.org/10.1164/rccm.201108-1428CI.

2. Tonelli AR, Brantly ML. Augmentation therapy in alpha-1 antitrypsin deficiency: advances and controversies. Ther Adv Respir Dis. 2010;4(5):289-312.

doi: https://doi.org/10.1177/1753465810373911.

3. Gadek JE, Klein HG, Holland PV, Crystal RG. Replacement therapy of alpha-1 antitrypsin deficiency. Reversal of proteaseantiprotease imbalance within the alveolar structures of $\mathrm{PiZ}$ subjects. J Clin Invest. 1981;68(5):1158-1165. doi: https://doi.org/10.1172/JCI110360.

4. Greene CM, Marciniak SJ, Teckman J, et al. a1-antitrypsin deficiency. Nat Rev Dis Primers. 2016;2:16051. doi: https://doi.org/10.1038/nrdp.2016.51 .

5. Jonigk D, Al-Omari M, Maegel L, et al. Anti-inflammatory and immunomodulatory properties of a1-antitrypsin without inhibition of elastase. Proc Natl Acad Sci USA. 2013;110(37):15007-150012.

doi: http://doi.org/10.1073/pnas.1309648110.

6. Tanash HA, Nilsson PM, Nilsson JA, Piitulainen E. Survival in severe alpha-1-antitrypsin deficiency (PiZZ). Respir Res. 2010;11:44. doi: http://doi.org/10.1186/1465-9921-11-44.

7. Lomas D, Parfrey H. a(1)-Antitrypsin deficiency • 4: molecular pathophysiology. Thorax. 2004;59(6):529-535. doi: http://doi.org/10.1136/thx.2003.006528.

8. Stoller JK, Tomashefski J, Jr., Crystal RG, et al. Mortality in individuals with severe deficiency of a1-antitrypsin: findings from the National Heart, Lung, and Blood Institute Registry. Chest. 2005a;127(4):1196-1204.

doi: https://doi.org/10.1016/S0012-3692(15)34467-6

9. de Serres FJ, Blanco I. Prevalence of a1-antitrypsin deficiency alleles $\mathrm{PI}^{*} \mathrm{~S}$ and $\mathrm{PI}^{*} \mathrm{Z}$ worldwide and effective screening for each of the five phenotypic classes $\mathrm{PI}^{*} \mathrm{MS}, \mathrm{PI}^{*} \mathrm{MZ}, \mathrm{PI}^{*} \mathrm{SS}, \mathrm{PI}{ }^{*} \mathrm{SZ}$, and PI*ZZ: a comprehensive review. Ther Adv Respir Dis. 2012;6(5):277-295.

doi: http://doi.org/10.1177/1753465812457113.

10. Stoller JK, Sandhaus RA, Turino G, Dickson R, Rodgers K, Strange C. Delay in diagnosis of alpha-1 antitrypsin deficiency: a continuing problem. Chest. 2005;128(4):1989-1994. doi: http://doi.org/10.1378/chest.128.4.1989.

11. Rachelefsky G, Hogarth DK. Issues in the diagnosis of alpha-1 antitrypsin deficiency. J Allergy Clin Immunol. 2008;121(4):833838. doi: http://doi.org/10.1016/j.jaci.2007.12.1183.
12. American Thoracic Society, European Respiratory Society. American Thoracic Society/European Respiratory Society statement: standards for the diagnosis and management of individuals with a1-antitrypsin deficiency. Am J Respir Crit Care Med. 2003;168(7):818-900. doi: http://doi.org/10.1164/rccm.168.7.818.

13. Kueppers F, Sanders C. State-of-the-art testing for alpha-1 antitrypsin deficiency. Allergy Asthma Proc. 2017;38(2):108-114. doi: http://doi.org/10.2500/aap.2017.38.4031.

14. Jacobsson K. Electrophoretic demonstration of two trypsin inhibitors in human blood serum. Scand J Clin Lab Invest. 1953;5(1):97-98.

15. Jacobsson KI. Studies on the determination of fibrinogen in human blood plasma. II. Studies on the trypsin and plasmin inhibitors in human blood serum. Scand J Clin Lab Invest. 1955; 7 (Suppl 14):3-102.

16. Laurell CB, Eriksson S. The electrophoretic a1-globulin pattern of serum in a1-antitrypsin deficiency. Scand J Clin Lab Invest. 1963;15(2):132-140. doi: http://doi.org/10.1080/00365516309051324.

17. Brantly ML, Wittes JT, Vogelmeier CF, Hubbard RC, Fells GA, Crystal RG. Use of a highly purified alpha 1-antitrypsin standard to establish ranges for the common normal and deficient alpha 1-antitrypsin phenotypes. Chest.1991;100(3):703-708. doi: http://doi.org/10.1378/chest.100.3.703.

18. Ferrarotti I, Thun GA, Zorzetto $M$, et al. Serum levels and genotype distribution of a1-antitrypsin in the general population. Thorax. 2012;67(8):669-674.

doi: http://doi.org/10.1136/thoraxjnl-2011-201321.

19. Burrows B. A clinical trial of efficacy of antiproteolytic therapy: can it be done? Am Rev Respir Dis. 1983;127(2):S42-43. doi: http://doi.org/10.1164/arrd.1983.127.2P2.S42.

20. Wewers MD, Casolaro MA, Sellers SE, et al. Replacement therapy for alpha 1-antitrypsin deficiency associated with emphysema. $N$ Engl J Med. 1987;316(17):1055-1062.

doi: http://doi.org/10.1056/NEJM198704233161704.

21. Barker AF, Iwata-Morgan I, Oveson L, Roussel R. Pharmacokinetic study of a1-antitrypsin infusion in a1-antitrypsin deficiency. Chest. 1997;112(3):607-613.

doi: http://doi.org/10.1378/chest.112.3.607.

22. Hubbard RC, Sellers S, Czerski D, Stephens L, Crystal RG. Biochemical efficacy and safety of monthly augmentation therapy for a1-antitrypsin deficiency. JAMA. 1988; 260(9):12591264. doi: http://doi.org/10.1001/jama.1988.03410090091037.

23. Stoller JK, Rouhani F, Brantly M, et al. Biochemical efficacy and safety of a new pooled human plasma a1-antitrypsin, Respitin. Chest. 2002;122(1):66-74.

doi: http://doi.org/10.1378/chest.122.1.66. 
24. Stocks JM, Brantly M, Pollock D, et al. Multi-center study: the biochemical efficacy, safety and tolerability of a new a1proteinase inhibitor, Zemaira. COPD. 2006;3(1):17-23. doi: http://doi.org/10.1080/15412550500493220.

25. Sandhaus RA, Stock J, Brantly M, Rouhani F, Strauss P, Tov N. Phase II/III randomized double-blind comparison of alpha-1 antitrypsin (Kamada-AAT) with active comparator in alpha-1 antitrypsin deficient subjects. Am J Resp Med Crit Care. 2009;276:A3513.

doi: http://doi.org/10.1164/ajrccm-conference.2009.179.1_Meeti ngAbstracts.A3513.

26. Campos MA, Kueppers F, Stocks JM, et al. Safety and pharmacokinetics of $120 \mathrm{mg} / \mathrm{kg}$ versus $60 \mathrm{mg} / \mathrm{kg}$ weekly intravenous infusions of alpha- 1 proteinase inhibitor in alpha-1 antitrypsin deficiency: a multicenter, randomized, double-blind, crossover study (SPARK). COPD. 2013;10(6):687-695. doi: http://doi.org/10.3109/15412555.2013.800852.

27. Sandhaus RA, Stocks J, Rouhani FN, Brantly M, Strauss P. Biochemical efficacy and safety of a new, ready-to-use, liquid alpha-1-proteinase inhibitor, GLASSIA (alpha1-proteinase inhibitor (human), intravenous). COPD. 2014;11(1):17-25. doi: http://doi.org/10.3109/15412555.2013.804500.

28. Barker AF, Campos MA, Brantly ML, et al. Bioequivalence of a liquid formulation of alpha1-proteinase inhibitor compared with prolastin(R)-C (lyophilized alpha1-PI) in alpha1-antitrypsin deficiency. COPD. 2017;14(6):1-7.

doi: http://doi.org/10.1080/15412555.2017.1376044.

29. Seersholm N, Sandhaus R, Chapman KR, et al. Safety of biweekly infusion of A1-PI augmentation therapy in RAPID. Eur Respir J. 2015;46:PA999.

doi: https://doi.org/10.1183/13993003.congress-2015.PA999

30. Tortorici MA, Rogers JA, Vit O, et al. Quantitative disease progression model of a-1 proteinase inhibitor therapy on computed tomography lung density in patients with a-1 antitrypsin deficiency. Br J Clin Pharmacol. 2017;83(11):23862397. doi: http://doi.org/10.1111/bcp.13358.

31. Sorrells S, Camprubi S, Griffin R, Chen J, Ayguasanosa J. SPARTA clinical trial design: exploring the efficacy and safety of two dose regimens of alpha1-proteinase inhibitor augmentation therapy in alpha1-antitrypsin deficiency. Respir Med. 2015;109(4):490499. doi: http://doi.org/10.1016/j.rmed.2015.01.022.

32. Seersholm N, Wencker M, Banik N, et al. Does alpha 1-antitrypsin augmentation therapy slow the annual decline in FEV 1 in patients with severe hereditary alpha1-antitrypsin deficiency? Wissenschaftliche Arbeitsgemeinschaft zur Therapie von Lungenerkrankungen (WATL) alpha1-AT study group. Eur Respir J. 1997;10(10):2260-2263. doi: http://doi.org/10.1183/09031936.97.10102260.
33. The Alpha-1-Antitrypsin Deficiency Registry Study Group. Survival and FEV 1 decline in individuals with severe deficiency of a1-antitrypsin. Am J Respir Crit Care Med. 1998;158(1):49-59. doi: http://doi.org/10.1164/ajrccm.158.1.9712017.

34. Wencker M, Fuhrmann B, Banik N, Konietzko N, for the Wissenschaftliche Arbeitsgemeinschaft zur Therapie von Lungenerkrankungen. Longitudinal follow-up of patients with a1-protease inhibitor deficiency before and during therapy with IV a1-protease inhibitor. Chest. 2001;119(3):737-744. doi: http://doi.org/10.1378/chest.119.3.737.

35. Chapman KR, Bradi AC, Paterson D, Navickis RJ, Wilkes MM. Slower lung function decline during augmentation therapy in patients with alpha1-antitrypsin deficiency (A1ATD): results from the Canadian AIR Registry. Proc Am Thorac Soc. 2005;2(A808).

36. Tonelli AR, Rouhani F, Li N, Schreck P, Brantly ML. Alpha1-antitrypsin augmentation therapy in deficient individuals enrolled in the Alpha-1 Foundation DNA and Tissue Bank. Int $J$ Chron Obstruct Pulmon Dis. 2009;4:443-452. doi: http://doi.org/10.2147/COPD.S8577.

37. Dirksen A, Dijkman JH, Madsen F, et al. A randomized clinical trial of alpha(1)-antitrypsin augmentation therapy. Am J Respir Crit Care Med. 1999;160(5):1468-1472.

doi: http://doi.org/10.1164/ajrccm.160.5.9901055.

38. Dirksen A, Piitulainen E, Parr DG, et al. Exploring the role of CT densitometry: a randomised study of augmentation therapy in alpha1-antitrypsin deficiency. Eur Respir J. 2009;33(6):13451353. doi: http://doi.org/10.1183/09031936.00159408.

39. Chapman KR, Stockley RA, Dawkins C, Wilkes MM, Navickis RJ. Augmentation therapy for a1 antitrypsin deficiency: a metaanalysis. COPD. 2009;6(3):177-184.

doi: http://dx.doi.org/10.1080/15412550902905961.

40. Ficker JH, Chapman KR, Turner AM, et al. Alpha 1 antitrypsin (A1-PI) treatment slows emphysema progression independent of baseline FEV 1 . Eur Respir J. 2017;50:OA3416. doi: https://doi.org/10.1183/1393003.congress-2017.OA3416.

41. Chorostowska-Wynimko J. Disease modification in emphysema related to alpha-1 antitrypsin deficiency. COPD. 2016;13(6):1-9. doi: https://doi.org/10.1080/15412555.2016.1178224.

42. Food and Drug Administration (FDA), Blood Products Advisory Committee. Clinical and surrogate endpoints for evaluating efficacy of alpha1-proteinase inhibitor (human) augmentation therapy. Wayback Archives website.

https://wayback.archive-it.org/7993/20170113022628/http:/www.fda. gov/downloads/AdvisoryCommittees/CommitteesMeetingMaterials/ BloodVaccinesandOtherBiologics/BloodProductsAdvisoryCommittee/ UCM171091.pdf Published 2009. Accessed 2018. 
43. Stockley RA, Parr DG, Piitulainen E, et al. Therapeutic efficacy of alpha-1 antitrypsin augmentation therapy on the loss of lung tissue: an integrated analysis of 2 randomised clinical trials using computed tomography densitometry. Respir Res. 2010;11:136. doi: http://doi.org/10.1186/1465-9921-11-136.

44. Chapman KR, Burdon JG, Piitulainen E, et al. Intravenous augmentation treatment and lung density in severe a1 antitrypsin deficiency (RAPID): a randomised, double-blind, placebo-controlled trial. Lancet. 2015;386(9991):360-368. doi: http://doi.org/10.1016/S0140-6736(15)60860-1.

45. McElvaney NG, Burdon JG, Holmes M, et al. Long-term efficacy and safety of a1 proteinase inhibitor treatment for emphysema caused by severe a1 antitrypsin deficiency: an open-label extension trial (RAPID-OLE). Lancet Respir Med. 2017;5(1):5160. doi: http://dx.doi.org/10.1016/S2213-2600(16)30430-1.

46. Parr DG, Dirksen A, Piitulainen E, Deng C, Wencker M, Stockley RA. Exploring the optimum approach to the use of CT densitometry in a randomised placebo-controlled study of augmentation therapy in alpha 1-antitrypsin deficiency. Respir Res. 2009;10:75. doi: https://doi.org/10.1186/1465-9921-10-75.

47. Green CE, Parr DG, Edgar RG, Stockley RA, Turner AM. Lung density associates with survival in alpha 1 antitrypsin deficient patients. Respir Med. 2016;112:81-87. doi: http://doi.org/10.1016/j.rmed.2016.01.007.

48. Dawkins PA, Dowson LJ, Guest PJ, Stockley RA. Predictors of mortality in a1-antitrypsin deficiency. Thorax. 2003;58(12):10201026. doi: http://dx.doi.org/10.1136/thorax.58.12.1020.

49. Rahaghi F, Monk R, Ramakrishnan V, Strange C. Alpha-1 antitrypsin augmentation improves survival in severely deficient individuals with low lung function. Am J Resp Crit Care Med. 2014;189:A5794.

50. Mannino DM, Tal-Singer R, Lomas DA, et al. Plasma fibrinogen as a biomarker for mortality and hospitalized exacerbations in people with COPD. Chronic Obstr Pulm Dis. 2015;2(1):23-34. doi: http://doi.org/10.15326/jcopdf.2.1.2014.0138.

51. Turino GM, Lin YY, He J, Cantor JO, Ma S. Elastin degradation: an effective biomarker in COPD. COPD. 2012;9(4):435-438. doi: http://doi.org/10.3109/15412555.2012.697753.

52. Ma S, Lin YY, He J, Rouhani FN, Brantly M, Turino GM. Alpha-1 antitrypsin augmentation therapy and biomarkers of elastin degradation. COPD. 2013;10(4):473-481.

doi: http://doi.org/10.3109/15412555.2013.771163.

53. Ma S, Lin YY, Cantor JO, et al. The effect of alpha-1 protease inhibitor (A1PI) on biomarkers of elastin degradation in alpha-1 antitrypsin deficiency (AATD): an analysis of the RAPID/ RAPID Extension trials. Chronic Obstr Pulm Dis. 2016;4(1):3444. doi: http://doi.org/10.15326/jcopdf.4.1.2016.0156.
54. Campos MA, Alazemi S, Zhang G, et al. Exacerbations in subjects with alpha-1 antitrypsin deficiency receiving augmentation therapy. Respir Med. 2009;103(10):1532-1539. doi: http://doi.org/10.1016/j.rmed.2009.04.008.

55. Lieberman J. Augmentation therapy reduces frequency of lung infections in antitrypsin deficiency: a new hypothesis with supporting data. Chest. 2000;118(5):1480-1485.

doi: http://dx.doi.org/10.1378/chest.118.5.1480.

56. Barros-Tizon JC, Torres ML, Blanco I, Martinez MT. Reduction of severe exacerbations and hospitalization-derived costs in alpha1-antitrypsin-deficient patients treated with alpha-1-antitrypsin augmentation therapy. Ther Adv Respir Dis. 2012;6(2):67-78. doi: http://doi.org/10.1177/1753465812438387.

57. Stockley RA. a1-antitrypsin: a polyfunctional protein? Lancet Respir Med. 2015; 3(5):341-343. doi: http://doi.org/10.1016/S2213-2600(15)00094-6.

58. Tawara I, Sun Y, Lewis EC, et al. Alpha-1-antitrypsin monotherapy reduces graft-versus-host disease after experimental allogeneic bone marrow transplantation. Proc Natl Acad Sci USA. 2012;109(2):564-569.

doi: http://doi.org/10.1073/pnas.1117665109.

59. Lewis EC, Mizrahi M, Toledano $M$, et al. a1-antitrypsin monotherapy induces immune tolerance during islet allograft transplantation in mice. Proc Natl Acad Sci USA. 2008;105(42):16236-16241.

doi: http://doi.org/10.1073/pnas.0807627105.

60. National Institutes of Health. A pilot study of alpha-1antitrypsin (AAT) in steroid refractory acute graft vs host disease (NCT01700036). ClinicalTrials.gov website. https:// clinicaltrials.gov/ct2/show/NCT01700036 Published 2016. Accessed October 2017.

61. National Institutes of Health. Alpha 1 anti-trypsin in treating patients with acute graft-versus-host disease (NCT01523821). ClinicalTrials.gov website. https://clinicaltrials.gov/ct2/show/ NCT01523821?term=AAT+alpha-1+proteinase+inhibitor\&ra nk=20.

Published 2012. Updated 2018. Accessed October 2017.

62. Rachmiel M, Strauss P, Dror N, et al. Alpha- 1 antitrypsin therapy is safe and well tolerated in children and adolescents with recent onset type 1 diabetes mellitus. Pediatr Diabetes. 2016;17(5):351359. doi: https://doi.org/10.1111/pedi.12283.

63. Gotzsche PC, Johansen HK. Intravenous alpha-1 antitrypsin augmentation therapy for treating patients with alpha-1 antitrypsin deficiency and lung disease. Cochrane Database Syst Rev. 2016;9:CD007851.

doi: https://doi.org/10.1002/14651858.CD007851.pub3.

64. Sandhaus RA, Turino G, Brantly ML, et al. The diagnosis and management of alpha-1 antitrypsin deficiency in the adult. Chronic Obstr Pulm Dis. 2016;3(3):668-682. doi: http://doi.org/10.15326/jcopdf.3.3.2015.0182. 
65. European Medicines Agency (EMA).Committee for Medicinal Products for Human Use assessment report: Respreeza. EMA website. https://www.ema.europa.eu/documents/assessment-re port/respreeza-epar-public-assessment-report_en.pdf Published 2015. Accessed October 2017.

66. Campos M, Geraghty P, Holt G, et al. The biological effects of double dose augmentation therapy for subjects with alpha-1 antitrypsin deficiency. Am J Crit Care Med. 2017;195: A6315. doi: http://doi.org/10.1164/ajrccmconference.2017.195.1_Meeting Abstracts.A6315.

67. Sandhaus RA, Turino G, Stocks J, et al. a1-Antitrypsin augmentation therapy for PI*MZ heterozygotes: a cautionary note. Chest. 2008;134(4):831-834.

doi: https://doi.org/10.1378/chest.08-0868

68. Brantly ML, Paul LD, Miller BH, Falk RT, Wu M, Crystal RG. Clinical features and history of the destructive lung disease associated with alpha-1-antitrypsin deficiency of adults with pulmonary symptoms. Am Rev Respir Dis. 1988;138(2):327-336. doi: https://doi.org/10.1164/ajrccm/138.2.327 . 